\title{
Immigration Policy and the U.S. Economy: An Institutional Perspective
}

Vernon M. Briggs, Jr.

By virtue of events that have already transpired and public policies already in place, the 1990s will witness the largest inflow of immigrants into the population and labor force of the United States of any decade in the nation's history. The revival of the phenomenon of mass immigration from out of the nation's past began in 1965. Policymakers did not intend for it to happen, and its consequences were unanticipated by the nation's citizenry. But it has. Indeed, a comprehensive study by an international panel of social science scholars concluded its assessment of U.S. society with the observation that "America's biggest import is people" and determined that "at a time when attention is directed to the general decline in American exceptionalism, American immigration continues to flow at a rate unknown elsewhere in the world" [Oxford Analytica 1986, 20]. Moreover, unlike earlier mass immigration periods to the United States, the post-1965 wave of immigrants shows "no sign of imminent decline" [Bouvier 1991, 18].

For a variety of reasons, immigration is a subject that is especially amenable to study and interpretation by institutional economists. In today's world setting, international migration is a discretionary action that is regulated by the specific actions of the governments of individual nation-states. To the degree mass immigration takes place, it is a policy-driven phenomenon.

There is no international obligation for any nation to allow others to enter or to work or to permanently settle within its geographical borders. In fact, most nations do not admit immigrants for permanent settlement. The Universal Declaration of Human Rights states that no nation-state should force people to stay within its bor-

The author is Professor of Labor Economics, Comell University. This paper was presented as the Presidential Address at the annual meeting of the Association for Evolutionary Economics, San Francisco, California, January 5-7, 1996. 
ders; but there is no parallel obligation on any nation to accept outsiders into its sovereign territory [United Nations 1948]. It is, therefore, one area of economic policymaking where market forces are not permitted to function.

\section{Human Migration in Long-Term Perspective}

The phrase "a nation of immigrants" is popularly used to describe the people who settled the United States. Historian Oscar Handlin added to the mythology when he opened his classic book The Uprooted by stating that "once I thought to write a history of the immigrants in America. Then I discovered that the immigrants were American history" [Handlin 1951, 3]. Even the Indians that the European explorers found and misnamed when they first encountered the New World were but earlier immigrants themselves from Asia to this continent. But Handlin's famous introductory sentence is a classic example of overstatement. For migration has been one of the most distinguishing behavioral characteristics of the entire human species. William McNeill, in describing the pre-modern experience, has written that "it is safe to assume that when out ancestors first became fully human they were already migratory" because they were already hunters and, he adds, that "no dominant species ever spread so far so fast" as have human beings [McNeill 1987, 15]. Until the modern era, however, there was little concern about how migrants might be received wherever they arrived. If the land area was unoccupied, the migrants settled it. If it was occupied, the newcomers might be absorbed if they came as individuals but, if in numbers, they often fought those already there with the outcome of the struggle often being death, enslavement, or exile for the losers. Indeed, the recorded history of mankind on every continent is a story of repeated invasions of one people by another. Looked at from a long-term evolutionary perspective, all existing countries are "nations of immigrants." It is only a matter of the length of the time frame. The only thing unique about the establishment of the English colonies in the land area later to become the United States is that the settlement process was not predicated on the idea of conquest of the indigenous people. But even then, of course, the ultimate result was the same.

In a finite spatial world that, in modern times, has been politically demarcated into nation states and economically organized by the pressures of industrialization and urbanization, the movement of people and workers was destined to encounter both geographic and manmade institutional barriers. So it has become that immigration policy is integrally related to the exercise of sovereignty power over land areas by every nation state on the planet today. 


\section{The Relevancy of the Institutional Approach}

Because, in the modern era, immigration policy is considered to be a discretionary power of national governments, immigration is not something that is necessarily "good" or "bad" or something about which to be "indifferent." It depends on the economic context in which it occurs. This is why the institutional approach is best suited for its analysis. As Edwin Witte, one of John Common's most famous students at Wisconsin, has written, "institutionalists do not regard economic laws to be timeless and placeless." Accordingly, Witte notes: "As they deal with public policy questions, they (i.e., institutionalists) seek not universal natural laws, but solutions applicable to a particular time, place, and situation" [Witte 1954, 134]. The efficacy of immigration and the role of immigration policy can only be understood within an evolutionary historical context of a particular nation's economic development. It is not an abstract concept, although U.S. politicians and immigrant advocate groups frequently discuss immigration as if it were a timeless principle of American life.

Immigration is a perfect example of what Sir John Hicks wrote about when he said that economics is only "on the edge" of being science but it can never be a true science "because the experiences that it analyzes have so much that is non-repetitive about them. . . . Economics is in time, and therefore in history, in a way that science is not" [Hicks 1986, 91-101]. Immigration, therefore, should not be discussed independent of the particular circumstances in which it occurs. Such circumstances are usually not repetitive over the course of a nation's history. Different times require different attitudes and different policy responses.

For this reason, the ahistorical approach associated with neoclassical economics as well as with many of the econometric studies that are constructed to test hypotheses based on this paradigm are particularly inappropriate for the study of the immigration experience. ${ }^{1}$ Indeed, William Baumol, a former president of the American Economic Association, has decried economic research on critical issues that rely exclusively on ex post data manipulations because they ignore efforts "to derive understanding from the explicit study of institutions and history" [Baumol 1990, 1715]. Baumol [1990, 1715] has called for a renewal of research that examines and explains "the substance of economic phenomena." In essence, he is arguing for an institutional approach to the study of such crucial issues as immigration.

Ironically, when it comes to the subject of immigration, the "Chicago School" of economics has conceded by default to the superiority of the institutional approach. Henry Simons, one of the intellectual founders of the "Chicago School" of free market economics, has written most forcefully against any neoclassical position that might favor the removal of restrictions on the international movement of labor. Simons has written:

Wholly free immigration, however, is neither attainable or desirable. To insist that a free trade program is logically or practically incomplete without 
free migration is either disingenuous or stupid. Free trade may and should raise living standards everywhere. . . . Free immigration would level standards, perhaps without raising them anywhere .. . As regards our import of populations, our plans and promises must be disciplined by tough-minded realism and political sense [1948, 251].

It was Simons's recommendation, therefore, that "as regards immigration policy, the less said the better" [1948, 251]. Milton Freidman, Simons's intellectual heir at Chicago, has taken Simons's advice to heart. Friedman completely ignored immigration policy in his famous book Capitalism and Freedom, in which he outlined his conception of the role of government in a market-oriented society. The same can be said for his treatment of immigration in his subsequent best seller, Free to Choose. Aside from some anecdotes about the positive adjustment experiences of a few immigrants at the turn of the twentieth century, the overall impact of immigration policy on the U.S. economy is ignored. Much of the advancement in real wages and expanded job opportunities that Friedman attributes in his books to the free market economic system for U.S. workers in general and black workers in particular occurred over the middle decades of the twentieth century. During these years, however, the United States had highly restrictive immigration policies in place, and immigration levels were declining. The beneficial labor market outcomes that accrued to the native-born labor force as a consequence of these governmental interventions to restrict immigration are simply ignored.

It is also bewildering that the praise Freidman heaps upon Margaret Thatcher in Free to Choose for the free market policies she championed as prime minister of Great Britain during the 1980 s does not mention the highly restrictive immigration policies she put in place during her tenure. In 1983, for example, Great Britain ended its policy of jus soli (i.e., the "right of soil"), which had been in effect for the preceding 750 years. No longer are people born in Great Britain automatically citizens of that country. Today, Britain's immigration policies are the most restrictive in Western Europe.

Likewise, Melvin Reder, also once a member of the Chicago economics faculty, has pointed out that "free immigration would cause a rapid equalization of per capita income across countries accomplished primarily by leveling downward the income of the more affluent" and, for this reason, he concluded, "I resist this proposal" [Reder 1982, 31]. Reder also notes that the United States and other "Western democracies" had, prior to the 1960s, made substantial progress toward improving the inequalities in income distribution within these nations as the result of "deliberate state action" to restrict immigration "over the prior 50 years" [Reder 1963, 230].

On the same day that it was announced that Gary Becker, another member of the Chicago economics faculty, had won the 1992 Nobel Memorial Prize in Economics, he published a commentary in The Wall Street Journal that explained why restrictive immigration policies were essential. He contrasted the economic setting of the 
United States at the beginning of the twentieth century with the economic setting at the end of the century and concluded:

But the world is now a very different place. Because of the expanded welfare state, immigration is no longer a practical policy. These days open immigration would merely induce people in poorer countries to emigrate to the United States and other developed countries to collect generous transfer payments [Becker 1992, A14].

In other words, there are historical realities associated with the differential development of social policies between nations that can be affected by immigration that policy must acknowledge.

Given these views, it is not surprising that the role of immigration as a potential influence on the supply of labor to would-be receiving nations is one of the least examined features of contemporary economic analysis. The leading advocates of the neoclassical paradigm have essentially agreed to say as little as possible on the subject. This posture clearly reflects a normative judgment on their part that such equilibrating adjustments derived from worldwide labor mobility are not in the national interest of receiving nations despite the alleged benefits that this model usually propounds to those who adopt its non-interventionist principles. In other words, they are agreeing with Hicks that immigration is a time-sensitive topic. Its merits depend on past historical events as well as present circumstances-not on theoretical dogma. As Reder [1963, 230] has succinctly observed, "immigration policy inevitably reflects a kind of national selfishness of which the major beneficiaries are the least fortunate among us. We could not completely abandon this policy even if we desired to do so."

Chicago-oriented economists do not specifically endorse the institutional economics approach to the subject of immigration. Nonetheless, they have certainly come to the same conclusion: governmental regulation of international labor mobility is in the national interest.

\section{The Evolution of U.S. Immigration Policy}

Immigration played a major role in the first half of the nineteenth century when the United States began to industrialize. Following the end of its colonial era in 1776 , the new nation expanded geographically to embrace a vast land area that had an abundance of natural resources and a temperate climate but relatively few people. Throughout its first century, the country had neither ceilings nor screening restrictions on the number and types of people permitted to enter for permanent settlement. The economy was dominated by agricultural production and farm employment. Most jobs required little in the way of training or educational preparation. An 
unregulated immigration policy was consistent with the nation's basic labor market needs during this crucial period of nation building.

When the industrialization process began in earnest during the latter decades of the nineteenth century, immigration again became of critical importance to the assembly of an urban labor force. The newly introduced technology of mechanization required mainly unskilled workers to fill manufacturing jobs in the nation's rapidly expanding urban labor markets as well as in the related-employment growth sectors of mining, construction, and transportation. As Stanley Lebergott [1964, 28] observed in his epic study of the development of the U.S. labor force, "somewhat surprisingly, the greatest beneficiaries of the flow of immigrant labor [in the nineteenth century] was never agriculture though farming was our primary industry. " Rather, it was the urban economy and its vast need for unskilled workers whose ranks were expanded by the arrival of immigrants.

There were surplus pools of native-born workers who were poorly skilled and barely educated who remained marginalized throughout the 1880-1914 era when the industrialization process took hold in earnest. They could have filled many of these new jobs. They were mostly native-born workers who were underemployed in the rural sectors of the economy. The most numerous were native born whites, but the most obvious were the freed blacks of the former slave economy of the rural South. The noted black educator Booker T. Washington, in his famous Atlanta Exposition speech in 1895, pleaded with the white industrialists of that era to draw upon the available black labor force instead of seeking immigrants to fill the new jobs that industrialization was creating [Washington 1965, 147]. If blacks were incorporated at this critical juncture of American economic development when entirely new industries were coming into being and an entirely new occupational structure was being created, Washington [1965, 148] said we could make "the interests of both races one." His advice was ignored. Mass immigration from Asia and Europe became the alternative of choice. Before long, immigration from China and Japan was banned in response to nativist reactions, so various ethnic groups from Eastern and Southern Europe became the primary sources of unskilled workers of that era.

Putting aside the equity opportunity that was lost and turning to the issue of efficiency, the mass immigration of the late nineteenth and early twentieth centuries was consistent with the prevailing labor market needs of the nation. The jobs created during this expansive era typically required little in the way of skill, education, literacy, numeracy, or fluency in English from the work force. The enormous supply of immigrants generally lacked these human capital attributes. As Peter Roberts, an immigration scholar at that time, wrote: "We may yearn for a more intelligent and better trained worker from the countries of Europe, but it is questionable whether or not that type of man would have been so well fitted for the work America had to offer" [Roberts 1913, 61]. In the same vein, Handlin [1951, 5] wrote: "It was the unique quality of the 19 th Century immigration that the people who moved, 
entered the life of the United States at a status equal to that of the older residents. The newcomers were one with those long settled in the New World." In terms of their political entitlements, their paucity of human capital endowments, and their low income status, there was little difference between the immigrants and the native-born workers of that era.

When America's frontiers were overcome in the $1890 \mathrm{~s}$, it was not long before immigration was sharply restricted-beginning in 1914 with the events associated with World War I and followed by newly adopted immigration laws in the early 1920s. In part, the imposition of legal restrictions reflected legitimate economic concerns that the mass immigration of the preceding three decades had depressed wages, hampered unionization, and caused unemployment. In part, they also reflected nativist social reactions to the ethnic, racial, and religious diversity that the mass immigration of that era also brought [Briggs 1984, 31-54]. The Immigration Act of 1924 (also known as the National Origins Act) not only imposed the first permanent legislative ceiling on immigration (at a low annual level of about 154,000 immigrants), but it also included an ethnic screening system that was highly discriminatory as to who could enter and who could not (favoring immigrants from Northern and Western European countries and disfavoring or prohibiting immigration from all other Eastern Hemisphere nations). Its restrictions, however, did not apply to countries of the entire Western Hemisphere.

For the next 50 years, the quantitative significance of immigration rapidly receded, and the expansion of the economy became dependent on the utilization of domestic labor reserves. Originally, it was those people in the nation's vast rural areas, where workers were being displaced by the rapid mechanization of agriculture, who were finally given the opportunity to compete for jobs in urban America. Among the major beneficiaries of the cessation of mass immigration was the nation's black population. It was not until mass immigration ended in 1914 that "the Great Migration" of blacks to the North and the West could commence. And it did. Later, during the war years of the 1940s, women, youth, disabled, and older workers, as well as minorities, were recruited and employed in the nation's economic mainstream for the first time.

Indicative of the declining significance of immigration on American life over this time span is the fact that the percentage of the U.S. population that was foreignborn consistently fell from 14.6 percent in 1910 to 4.7 percent in 1970 (the lowest percentage since before the Civil War). During this long interval of the receding influence of immigration, the U.S. economy sustained the greatest increases in real wages, employment levels, and production output in its economic history. It was also the time when the nation adopted an extensive array of progressive social policies pertaining to labor standards, collective bargaining, and civil rights. It was also a period when income inequality within the population was significantly reduced for the first time since the nation was founded. 


\section{The Revival of Mass Immigration}

In the mid-1960s, the phenomenon of mass immigration was accidently revived as a result of domestic political pressures. The primary concern of immigration reformers at the time was to end the discriminatory "national origins" admission system. Having just enacted the Civil Rights Act of 1964 that was designed to end overt racial and ethnic discrimination in the nation's internal relationships, the logical next step was to end overt discrimination in the nation's external relationships with the international community. The immigration reformers, however, "were so incensed with the ethnocentrism of the laws of the past that they spent virtually all of their energies seeking to eliminate the country of origin provisions" and, as a consequence, "they gave very little attention to the substance or long range implications of the policy that would replace them" [North and Houstoun 1976, 5]. In a nutshell, that is what has subsequently occurred. It is a story of unintended consequences [Briggs 1992, chap. 6].

There was no intention to raise the level of immigration by any appreciable amount or to open the admission door to large numbers of unskilled and poorly educated persons. There was no shortage of labor in 1965 that required an increase in immigration. Indeed, 1965 was exactly the year that the postwar "baby boom" hit the labor market. One million more people turned 18 years old (the primary labor force entry age for full-time job seeking) that year, and the high level of entry persisted for the next 16 years. Already worried about the adverse effects of foreign workers on citizen workers, the Johnson administration had terminated the Mexican Labor Program (i.e., the infamous "bracero program") only 10 months before the Immigration Act of 1965 was signed. Moreover, in the presidential campaign of 1964, the Republican party had raised the specter of massive job displacement if the proposed immigration legislation (initially proposed in 1963 by the Kennedy administration) were to be enacted by the Johnson administration after the election ["Should the Gates . . ." 1964, 114]. Congress was sensitive to the charge of possible adverse labor market impacts of immigrants and, for that reason, it significantly tightened the labor certification requirements that applied to non-family and nonrefugee admissions that were contained in the Immigration Act of 1965.

The key features of the Immigration Act of 1965 that have instrumentally affected subsequent events transcend the vision of ending overt ethnocentrism. Prior to its passage, the preference system that had been in place since 1952 and that was superimposed on the basic national origins selection system was one that set human resource concerns as the major objective of the nation's immigration policy. Half of all available visas were set aside for this group. The Immigration Act of 1965, however, introduced the notion of "family reunification" as the highest priority-setting aside 74 percent of the visas for such persons (later increased to 80 percent in 1980). The concept embraces not only nuclear family members, but also extended family members. In the process, it downgraded labor needs of the nation to both 
smaller numbers and lower preference levels. Thus, the focus of the nation's immigration policy shifted. Had the scale of immigration remained at its low pre-1965 levels, this shift in focus may not have proved significant. But, immigration has increased dramatically, and the human capital attributes of ensuing inflow has been entirely counter to the post-1965 trends of the labor market.

Furthermore, the Immigration Act of 1965 also introduced a preference category for the admission of refugees. This is the first time in the history of the U.S. immigration law that refugees were given statutory recognition as being a permanent feature of the U.S. immigration policy. Refugees, mostly from the Third World, have proven to be a major source of post-1965 immigrants and, subsequently, of additional family-related immigrants.

The Act of 1965 is also significant for what it did not do. Namely, it failed to address the ongoing problem of illegal immigration. It did not contain any forms of deterrence. By its silence, the legal loophole in earlier legislation that exempted employers from being prosecuted for hiring illegal immigrants was perpetrated. Following its passage, illegal immigration simply exploded in scale.

It is obvious, in retrospect, that the nation-changing ramifications of the Immigration Act of 1965 were not foreseen by its proponents at the time of its passage. In testimony prior to its passage, Secretary of State Dean Rusk stated that "the significance of immigration for the United States now depends less on numbers than on the quality of the immigrants" ["Statement' of Secretary . . ." 1965, 276]. Congressman Emanuel Celler, the sponsor of the bill in the House of Representatives, stated during the final floor debate that "there will not be comparatively, many Asians or Africans entering the country. . . . since few could immigrate from those countries because they have not family ties to the United States" [U.S. Congress 1965b, 21,758]. Senator Edward Kennedy, the floor manager of the bill in the Senate, stated "this bill is not concerned with increasing immigration to this country, nor will it lower any of the high standards we apply in the selection of immigrants" [U.S. Congress 1965c, 24, 225]. Kennedy also said "our cities will not be flooded with a million immigrants annually"; that "the ethnic mix of this country will not be upset"; and "it (the pending bill) would not cause American workers to lose their jobs" [U.S. Congress 1965a, 1-3]. As subsequent research has shown, none of these assurances proved to be true.

Subsequent legislation and related developments have also greatly expanded the number of foreign nationals who are legally permitted to work temporarily in the United States in occupations that compete with U.S. citizens. These foreign workers (who are called "non-immigrant workers" in immigration law) cover the gamut of occupations (e.g., apple pickers, fast food servers, nurses, engineers, computer programmers, and professors) [Briggs 1984, 172-177; 1983, 609-630]. They may work in the United States for periods that range from a few months to up to six years. More than one-half million such workers are legally admitted to work each year. 
Also, in 1980, U.S. immigration policy was expanded by the addition of a political asylum policy [Briggs 1984, 128-150]. It was intended to address the issue of persons who arrive in the United States (as opposed to refugees who are screened for admission abroad) and who claim they will be persecuted if they are forced to return to their homelands. The full implications of this policy were not thought through at the time. Consequently, it has become a major source of controversy over the succeeding years as it has become involved in U.S. foreign policy issues (e.g., persons fleeing from Cuba versus those from Haiti) and contemporary political disputes (e.g., people fleeing from China's "one child per couple" population policy). As a consequence, there were 425,000 backlogged asylum cases pending as of the beginning of 1995. Immigration policy, therefore, has multiple dimensions.

\section{The Economic Consequences of Post-1965 Immigration}

The Immigration Act of 1965 was a turning point in the history of U.S. immigration policy. The most obvious effect of the changes caused by that legislation (which have been followed by the Refugee Act of 1980, the Immigration Reform and Control Act of 1986, and the Immigration Act of 1990) has been a significant increase in the size of the foreign-born population. The foreign-born population has grown from 4.7 percent of the total population in 1970 to 8.7 percent of the population in 1994 (or about one of every eleven people in the population). In absolute terms, the foreign-born population has increased from 9.6 million persons in 1970 to 22.8 million persons in 1994 (an increase of 137 percent). Of these, 4.5 million persons arrived since 1990. Making an allowance of the undercount of illegal immigrants, the actual inflow has certainly exceeded a million a year in most of the 1980 s and all of the 1990s to date. The inflow, however, has been exceedingly uneven in terms of where the immigrants have come from. Twenty-eight percent of the entire foreign-born population in 1994 have come from only one country-Mexico.

But the immigrant population is younger than the native-born population and contains more men than women; hence, the impact of immigration on the labor force is significantly greater than is revealed by population statistics. Indeed, in 1994 the foreign-born accounted for $\mathbf{1 0 . 8}$ percent of the labor force (or one of every nine members of the U.S. labor force) [U.S. Department of Labor 1995]. These figures must also be viewed as minimal rates as there is a sizable undercount of the number of illegal immigrants present in the country. ${ }^{2}$

If the revival of mass immigration since 1965 had been evenly distributed across the country, the incongruity of the subsequent immigrant inflow would have been less dramatic than it has been. A key feature of the post-1965 mass immigration, however, has been its geographic concentration. Five states (California, New York, Florida, Texas, and Illinois) account for 65 percent of the entire foreign-born popu- 
lation and 68 percent of the entire foreign-born labor force. It is also the case that the foreign-born are overwhelmingly concentrated in only a handful of urban areas. But these particular labor markets are among the nation's largest in size, which greatly increases the significance of their concentration. These five metropolitan areas in 1994 were Los Angeles, New York, Miami, Chicago, and Washington, D.C. Collectively, they accounted for 51 percent of all foreign-born workers in 1994. The concentration in the central cities of the nation is even more extreme. The 1990 Census, for instance, revealed that the percentage of the population that is foreignborn of Miami was 60 percent; in New York City, 28 percent; for Los Angeles, 38 percent; for San Francisco, 34 percent; and for Chicago, 17 percent. The percentage of the labor force that was foreign-born, of course, is higher in each of these cities than these population percentages show.

The flow of immigrants into the United States has tended to be bimodal in terms of their human capital attributes (as measured by educational attainment), but the highest concentration by far is in the lowest end of the nation's human capital distribution. The 1990 Census revealed that the percentage of foreign-born adults ( 25 years and over) who had less than a ninth grade education was 25 percent (compared to only 10 percent for native-born adults) and whereas 23 percent of nativeborn adults did not have a high school diploma, 42 percent of foreign-born adults did not. Immigration, therefore, is a major contributor to the nation's adult illiteracy problem. On the other hand, both foreign-born adults and native-born adults had the same percentage of persons who had a bachelor's degree or higher (20.3 percent and 20.4 percent, respectively), but with regard to those who had graduate degrees, foreign-born adults had a considerably higher percentage than did the native-born, 3.8 percent versus 2.4 percent. Thus, it is at both ends of the U.S. labor force that immigration has its greatest impacts-at the bottom and at the top of the economic ladder.

In the low-skilled labor market, immigration has increased the competition for whatever jobs are available. In recent years, unskilled jobs have not been increasing as fast as have the number of unskilled workers. As for skilled jobs, immigration can be useful in the short run as a means of providing qualified workers where shortages of qualified domestic workers exist. But, the long-term objective should be that these jobs should go to citizens and resident aliens. As the Commission on Workforce Quality and Labor Market Efficiency warned the U.S. Secretary of Labor in 1989, "by using immigration to relieve shortages, we may miss the opportunity to draw additional U.S. workers into the economic mainstream" [CWQLME $1989,32]$. It concluded by stating that public policy should "always try to train citizens to fill labor shortages" [CWQLME 1989, 32]. No industry should have unlimited access to the possibility of recruiting immigrant and non-immigrant foreign workers. Shortages should be signals to the nation's education and training system 
to provide such workers and for private employers to initiate actions to overcome these shortages. They should not be excuses to increase skilled immigration per se.

The effects of the human capital variation between the foreign-born and nativeborn, not surprisingly, are reflected in a comparison of their 1994 occupational distributions. Twenty-six percent of the foreign-born labor force were employed in the low-skilled and semi-skilled occupations as operatives, laborers, or farm workers (compared to 17 percent of native-born workers).

The disproportionate concentration of the foreign-born who lack even a high school diploma is also reflected in their unemployment experiences. The overall unemployment rate of foreign-born workers in 1994 was 9.2 percent, while the comparable national unemployment rate at the time was 6.5 percent. Consequently, immigration is pulling up the national unemployment rate. The unemployment rate for foreign-born workers with less than a ninth grade education in 1994 was 13 percent; for those with some high school but no diploma, it was 15.2 percent. The comparable rates for native-born workers were 13.5 percent and 29.9 percent. Consequently, the greatest labor market impact of immigration is in the sector of the labor market that is already having the greatest difficulty finding employment. It is, therefore, the least skilled segment of the labor force (using educational attainment as the usual proxy for skill) who are bearing the brunt of the direct job competition with immigrant workers. There certainly is no shortage of unskilled native-born workers as indicated by their high unemployment rates and by the number of adult illiterates (estimated to be more than 27 million persons).

As for the racial and ethnic composition of the immigration phenomenon, immigrants from Asia and Latin America overwhelmingly dominate the current inflow. Immigrants from Asia and Latin America account for more than 80 percent of the post-1965 immigrants. Indeed, Asia emerged in the 1990s as the primary immigrant source region. As of 1994, 62 percent of the Asian population of the United States were foreign-born with 92 percent of such persons entering the United States since 1970. As for the Hispanic population, 39 percent were foreign-born in 1994 with more than one-half of the Hispanic labor force being foreign-born ( 51.2 percent). In contrast, only 3 percent of the non-Hispanic white labor force was foreign-born and only 4 percent of the black non-Hispanic labor force in 1994 were foreign-born. Thus, the most distinguishing feature of the Asian and Hispanic labor forces is the inordinately high proportion who are foreign-born. Immigration, accordingly, is significantly altering the racial and ethnic composition of both the nation's population and labor force.

The 1990 Census also disclosed that 79.1 percent of the foreign-born population (five years old and over) speak a language other than English (compared to 7.8 percent of the native-born) and that 47.0 percent of the foreign-born (five years and over) reported that they do not speak English "very well." The ability to speak English in an increasingly service-oriented economy has been definitively linked to the 
ability to advance in the U.S. labor market of the post-1965 era [Chiswick 1992, 15].

For these reasons and others, it should come as no great revelation that the incidence of poverty among families of the foreign-born population in 1990 was 50 percent higher than that of native-born families or that 25 percent of the families with a foreign-born householder who entered the country since 1980 were living in poverty in 1990. Nor is it surprising to find that immigrant families make greater use of welfare than do native-born families [Borjas and Trejo 1991, 195-211].

The human capital deficiencies of adult immigrants has dire intergenerational consequences on the preparation of their children to become future workers. It is estimated that 2 million immigrant youth enrolled in U.S. public schools in the 1980s. Studies of these immigrant children indicate that they are "twice as likely to be poor as compared to all students, thereby straining local school resources" [U.S. General Accounting Office 1994, 2]. Moreover, "many immigrants, including those of high school age, have had little or no schooling and are illiterate even in their native languages" [U.S. General Accounting Office 1994, 2]. New demands for the creation of bilingual programs and special education classes have significantly added to the costs of urban education and have frequently led to the diversion of funds from other important programs for other needy children [Rivera-Batiz 1995, 84-89]. Overcrowding of urban school systems, already confronting enormous educational burdens, has frequently occurred with devastating impacts on the educational process [e.g., Firestone 1994, Al]. Other educational costs to social policy are more subtle but equally as significant as the financial concerns. Namely, the societal goal of desegregated urban schools has been greatly retarded by the arrival of immigrant children because it has increased the racial isolation of inner-city black children [Fiske 1988, A16].

There is also the issue of job competition, which is the hardest to prove. Logic would indicate that, if immigrants are disproportionately concentrated in the nation's largest urban labor markets and if foreign-born workers are disproportionately lacking in human capital attributes, and if they are overwhelmingly minority group members themselves, it would be similarly situated native-born workers (actual and potential) who experience the greatest competition with immigrants for jobs. But developing a methodology to measure displacement has proven to be an insurmountable feat. Not only is it impossible to prove that if one person is hired, someone else has been displaced, but even if such a straightforward approach were feasible, it would not settle the issue. There is no way to ascertain who else would have moved to the high-immigrant impact cities if the immigrants were not pouring into those same labor markets. Moreover, there is no way to measure the number of people who have left these same local labor markets in despair who might otherwise have retained their jobs or had higher wages if not for the presence of newly arrived immigrants. Research on these mobility issues has found that the internal immigration 
patterns of the native-born labor force to the urban areas where immigrants are concentrated has been reduced [Walker et al. 1993, 234-248]. Still other research has found that immigrants themselves are less likely to move out of states where they are concentrated than are the native-born [Kritz and Nogle 1994, 1-16]. Both features can cause an accentuation of the impact on those labor markets where immigrants are concentrated. Furthermore, research shows those urban cities in California that have experienced quantum increases in immigration have seen the "flight" of low-income, poorly educated citizen workers out of their former communities to outer fringes of their metropolitan areas or to other states [Frey 1995, 353-375]. This means that they have lost the competitive struggle for jobs with low-skilled, poorly educated immigrants and that these other labor markets are now not confronted with trying to accommodate the outflows of unskilled citizen and resident alien job seekers. The same can be said of wage rates. If the immigrants had not entered these local labor markets in substantial numbers, wages should have risen, which would have attracted citizens to move in or to stay in these cities.

While the direct displacement issue cannot be definitively resolved, the substitution of immigrant workers for native-born workers can be described. Unfortunately, this type of work requires case studies of occupational patterns in high immigrant impact cities. Few have been conducted. One excellent study in southern California clearly documented the situation whereby black janitorial workers, who had successfully built a strong union in the 1970s that provided high wages and good working conditions, were almost totally displaced and the union broken by Hispanic immigrants in the 1980s who were willing to work for far lower pay and with few benefits [Mines and Avina 1992, 429-448]. More such case research is desperately needed.

Finally, but without question, the most serious finding concerning post-1965 immigration is the adverse effect it has had on income distribution. The Economic Report of the President: 1994 stated that "immigration has increased the relative supply to less educated labor and appears to have contributed to the increasing inequality of income" in the United States [Economic Report 1994, 170]. Given the aforementioned indicators, this conclusion is not a surprise, but it is the most significant indictment of prevailing policy.

\section{The Post-1965 Transformation of U.S. Employment Patterns}

Although the signs were already present in the mid-1960s that the demand for labor in the United States was being transformed, it was still a subject of debate-not yet a confirmed reality. Labor economists were arguing that the structure of labor demand was being reconstituted. But the warnings were ignored at the time by those who said that the unemployment of that era was essentially a cyclical issue. By the 1990 s, virtually everyone acknowledges that unemployment is a structural issue and 
that the imbalance between the demand and the supply of labor is growing worse. Employment growth in the major goods-producing sectors that had spawned economic growth in the first half of the twentieth century is no longer occurring. A significant shift to the service sector is in progress. It has accounted for literally all of the job growth that has occurred since the mid-1960s. By 1994, almost 80 percent of all jobs were in the service sector, and it is projected that 95 percent of the job growth in the remainder of 1990 s will occur in the service sector. The greatest growth in service employment has occurred in the occupations that have the highest requirements for educational achievement (i.e., jobs in the professional, managerial, executive, administrative, and technical occupations). The shift to services has placed an emphasis on cognitive abilities, not manual effort. Technological development, spawned by the computer revolution, has led to increases in output but with declining needs for labor inputs [Franklin 1993, 41-57]. In every occupational category, the percentage of workers in non-production (i.e., white-collar workers) has increased sharply, while the proportion in production jobs (i.e., blue-collar jobs) has fallen precipitously. It has been jobs at the lower skill levels that have been most impacted by these contractive trends. But in the $1990 \mathrm{~s}$, even jobs for many skilled workers have come under attack. The unexpected end of the Cold War has led to extensive reductions in the ranks of the armed forces and the work forces of the private sector defense contractors [Saunders 1993, 3-10]. Likewise, the corporate fad in the 1990 s to downsize their employment rolls and the surge in mega-mergers to reduce the number of competitors have both added to the employment instability of workers at all skill levels [Cappelli 1994, 5-11; Katz 1994, 15-19].

All of this uncertainty has been compounded by the decision of the United States in the early 1960 s to embrace international competition. The U.S. economy was not built on the principle of free trade. Indeed, it was built behind high protective tariff walls that existed until the 1960s (and in practice until the 1980s). The implementation of free trade policies has been a voyage into unchartered waters. The advent of U.S. participation in the North American Free Trade Agreement and adherences to the provisions of the General Agreement on Tariffs and Trade have all led to a greater vulnerability of U.S. workers to international job competition and of the U.S. economy to job losses.

Theoretically, the benefits of free trade are based on the premise that it will cause income distribution changes to occur within each trading nation. But, as Lester Thurow $[1992,82]$ has poignantly written: ". . . average incomes will go up with free trade, but there will be millions of losers in each country. . . . The theory simply maintains that the losses of the losers will simply be smaller than the winnings of winners." The job losers, in the contemporary case of the United States, are those unskilled and poorly educated workers who, under protectionism, were previously able to secure jobs-often with high wages. Disproportionately, they are workers from minority groups. Those in the manufacturing sector have been espe- 
cially vulnerable. The winners are high-skilled and better-educated workers who often are employed in service industries. Thurow [1992, 82] also notes that ". . . the theory assumes that the winners will compensate the losers so that everyone in each country has an incentive to move to free trade but, in fact, such compensation is almost never paid." With the exception of a few provisions for retraining some displaced workers, there are no compensation provisions in any of the new trade policies adopted by the United States. Even those few retraining programs, however, are currently under attack by budget cutters in Congress.

\section{Political Rhetoric and Non-Repetitive Circumstances}

When the "nation of immigrants" rhetoric is put aside, it is clear that immigration is not a universal principle whose efficacy is immune from the changes in economic circumstances. In the nineteenth and early twentieth centuries, mass immigration was consistent with the economic needs of the nation. Agriculture was still the major employment sector, but the non-agricultural sector was in the process of being industrialized. The introduction of mechanization created millions of jobs for unskilled, poorly educated, non-English speaking workers in urban centers. It was a time when high tariffs were in place that protected the business sector from foreign competitors. It was when the work standards (i.e., laws covering minimum wages, child labor, hours worked, health and safety requirements, and collective bargaining protection) were virtually nonexistent. There were no income maintenance programs in place to provide a safety net for the uncertainties of life (e.g., unemployment compensation, food stamps, supplemental security income, aid for dependent children, Social Security, or Medicare and Medicaid). Likewise, it was a period when there was no concern about equal employment opportunity needs for native-born citizens.

As discussed, the phenomenon of mass immigration then went into remission for 50 years in 1914 before being accidentally revised in 1965 . Unfortunately, while the post-1965 immigrants resemble in many ways the immigrants of the earlier era in terms of their economic characteristics and their settlement patterns, the U.S. economy in no way is similar to that of the earlier era. As a consequence, the immigrants are quite different from the general citizen population in terms of their human capital attributes and employment patterns. The immigrants are disproportionately poor, uneducated, unskilled, non-English speaking, and are overwhelmingly members of racial and ethnic groups themselves. Like in the past, the immigrants tend to settle in the central cities of the nation's largest labor markets.

But the jobs that are now being created are knowledge-based. They require workers who are empowered with skills and education to fill them. It is a serviceoriented economy and not a goods-producing economy. Cognitive abilities-reading, writing, and speaking of English-are employment imperatives. The ability to work 
with other employees, to follow employer's instructions, and to relate directly to customers are all essential communication skills. The employment growth centers are more dispersed because, unlike the employment patterns of the earlier goodsproducing enterprises, which were geographically concentrated, service jobs are less geographically concentrated because they have to be provided where people actually are. Job growth is not in the central cities but, rather, in surrounding metropolitan areas. Furthermore, the nation has developed a costly social system that is designed to protect those in our society who experience unemployment and social hardship but which has its political limits in terms of the adequacies of its coverages and benefit levels it is willing to and can provide. It is also a time when the labor market is under unprecedented challenges to purge itself of past discriminatory behavior and to incorporate previously excluded groups, and when the labor force has been experiencing unprecedented growth that is generated by internal forces. These growth forces are associated with the demographic positioning of the "baby boom" generation into its primary working age as well as the unprecedented increases in the labor force participation of women. Likewise, the economy has been opened to foreign competition for the first time. In such a situation, productivity is the only way for the country to remain competitive, for real wages to increase, and for jobs to remain available within its borders. A highly skilled, motivated, and educated labor force is imperative.

The consequences of the pursuit of the political objective of mass immigration at this juncture in the nation's evolutionary development is in direct conflict with the attainment of the nation's economic objectives. A course correction is long overdue. History, as Hicks said, is not repetitive regardless of opportunistic platitudes by politicians or George Santayana's famous dictum to the contrary. The appropriate immigration policy for the nation depends entirely on its congruence with the circumstances of the present, not of the past. As Thorstein Veblen said:

... the habits of thought under the guidance of which men live are received from an earlier time. . . . [As a consequence, they] are adapted to past circumstances, and are, therefore never in full accord with the requirements of the present [Veblen 1959, 133].

The resurrection of mass immigration from out of the nation's distant past was a political accident; its perpetuation in the $1990 \mathrm{~s}$ is contrary to national interest. Immigration reform, therefore, needs to be the forefront of the nation's economic policy agenda. 


\section{Notes}

1. For example, see Borjas [1994] for a discussion about changes in "the immigration market."

2. For the most recent effort to estimate the illegal immigrant population as of 1992 , see 1993 Statistical Yearbook of the Immigration and Naturalization Service [1994, 182-183]. It placed the stock of illegal immigrants at 3.4 million persons with an additional annual flow of 300,000 illegal entrants a year. For comments on the undercount issue as it relates to employment data, see Flaim [1989].

\section{References}

Baumol, William J. "Sir John Versus the Hicksians, or Theorist Malgre Lui." The Joumal of Economic Literature 19, no. 4 (December 1990): 1708-1715.

Becker, Gary S. "An Open Door for Immigrants-the Auction." The Wall Street Joumal, 14 October 1992, p. A-14.

Borjas, George J. "The Economics of Immigration." The Joumal of Economic Literature 23, no. 4 (December 1994): $1667-1717$.

Borjas, George J., and Stephen J. Trejo. "Immigrant Participation in the Welfare System." Industrial and Labor Relations Review 44, no. 2 (January 1991): 195-211.

Bouvier, Leon. Peaceful Invasions: Immigration and Changing America. Washington, D.C.: Center for Immigration Studies, 1991.

Briggs, Vernon M., Jr. "Non-Immigrant Labor Poljcy in the United States." Joumal of Economic Issues 17, no. 3 (September 1983): 609-630. 1984

Immigration Policy and the American Force. Baltimore: The Johns Hopkins University Press,

. Mass Immigration and the National Interest. Armonk, N.Y.: M.E. Sharpe, Inc., 1992.

Cappelli, Peter. "Forces Driving the Restructuring of Employment." Looking Ahead 16, nos. 2-3 (1994): $5-11$.

Chiswick, Barry R., ed. Immigration, Language, and Ethnicity: Canada and the United States. Washington, D.C.: The American Enterprise Institute, 1992.

Economic Report of the President: 1994. Washington, D.C.: U.S. Government Printing Office, 1994.

Firestone, David. "Crowded Schools in Queens Find Class Spaces in Unusual Places." New York Times, 8 June 1994, p. A-2.

Fiske, E. "Racial Shifts Challenge U.S. Schools." New York Times, 23 June 1988, p. A-16.

Flaim, Paul. "How Many Jobs Since 1982? Data From Two Surveys Differ. "Monthly Labor Review 112 , no. 8 (August 1989): 10-15.

Franklin, James C. "Industry Output and Employment." Monthly Labor Review 116, no. 11 (November 1993): 41-57.

Frey, William. "Immigration and Internal Migration." Population and Environment 16, no. 4 (March 1995): 353-375

Handlin, Oscar. The Uprooted. New York: Grosset and Dunlap Publishers, 1951.

Hicks, John. "Is Economics a Science?" In Foundations of Economics: Structures of Inquiry and Economic Theory, edited by Mauro Barazino and Roberto Scazzieri, 91-101. Oxford: Blackwell Publishing Co., 1986.

Katz, Harry C. "Downsizing and Employment Security." Looking Ahead 16, nos. 2-3 (1994): 15-19.

Killingsworth, Charles. "The Fall and Rise of the Idea of Structural Unemployment." Proceedings of the 31st Winter Meetings of the Industrial Relations Research Association. Madison: Industrial Relations Research Association, 1979, pp. 3-10. 
Kritz, Mary, and June Marie Nogle. "Nativity Concentration and Internal Migration Among the ForeignBorn." Demography 31, no. 3 (August 1994): 1-16.

Lebergott, Stanley. Manpower in Economic Growth. New York: McGraw Hill Book Company, 1964.

McNeill, William H. "Migration in Pre-Modern Times." In Population in an Interacting World, edited by William Alonzo, 15-35. Cambridge: Harvard University Press, 1987.

Mines, Richard, and Jeffrey Avina. "Immigrants and Labor Standards: The Case of California." In U.S. Mexico Relations: Labor Market Interdependence, edited by Jorge Bustamonte et al., 429-448. Stanford: Stanford University Press, 1992.

North, David, and Marion Houstoun. The Characteristics and Role of Illegal Aliens in the U.S. Labor Market: An Exploratory Study. Washington, D.C.: Linton and Company, Inc., 1976.

Oxford Analytica. America In Perspective. Boston: Houghton-Mifflin, 1986.

Reder, Melvin. "The Economic Consequences of Increased Immigration." The Review of Economics and Statistics 45, no. 3 (August 1963): 221-230.

"Chicago Economics: Permanence and Change." Journal of Economic Literature 20, no. 1 (March 1982): 1-38.

Rivera-Batiz, "Immigrants and Schools: The Case of the Big Apple." Forrom for Applied Research and Public Policy 10, no. 3 (Fall 1995): 8489.

Roberts, Peter. The New Immigration. New York: The Macmillan Company, 1913.

Saunders, Norman. "Employment Effects of the Rise and Fall in Defense Spending." Monthly Labor Review 116, no. 11 (November 1993): 3-10.

"Should the Gates be Opened Wider?" Business Week (October 17, 1964): 114.

Simons, Henry C. Economic Policy for a Free Society. Chicago: University of Chicago Press, 1948.

"Statement" of Secretary of State Dean Rusk before the Subcommittee on Immigration, U.S. Senate, Committee on the Judiciary as reprinted in "Department Urges Congress to Revise Immigration Laws." The Department of State Bulletin. Washington, D.C.: U.S. Department of State, August 24, 1965, p. 276.

Thurow, Lester. Head to Head: The Coming Economic Batle Among Japan, Europe, and America. New York: William Morrow and Co., Inc., 1992.

United Nations Declaration of Human Rights, Articles 13 and 14. Adopted by the General Assembly of the United Nations on December 10, 1948.

United States Congress. Senate, Subcommittee on Immigration and Naturalization of the Committee on the Judiciary. Hearings, February 10, 1965. Washington, D.C.: U.S. Government Printing Office, 1965 a, pp. 1-3.

House of Representatives, Congressional Record. 89th Congress, 1st Session, August 25, 1965. Washington, D.C.: U.S. Government Printing Office, 1965b, p. $21,758$.

Senate, Congressional Record. 89th Congress, 1st Session. September 17, 1965. Washington, D.C. U.S. Government Printing Office, 1965c, p. 24, 225.

U.S. Department of Labor. "Labor Force, Income, and Poverty Statistics for the Foreign-Born Using the March 1994 Current Population Survey," Special Report. Washington, D.C.: Bureau of International Labor Affairs, 1995.

U.S. General Accounting Office. "Statement of Linda Morra, Director of Education and Employment Issues, Health Education, and Human Services Division to U.S. Senate Committee on Labor and Human Resources." Immigrant Education. GAD/T-HEHS - 94 - 1946 (April 14, 1994).

U.S. Immigration and Naturalization Service. 1993 Statistical Yearbook of the Immigration and Naturalization Service. Washington, D.C.: U.S. Government Printing Office, 1994.

Veblen, Thorstein. The Theory of the Leisure Class. New York: The New American Library, 1959.

Witte, Edwin E. "Institutional Economics as Seen by an Institutional Economist." Southem Economic Joumal 21, no. 2 (October 1954): 131-140.

Walker, Robert, Mark Ellis, and Richard Barff. "Linked Migration Systems: Immigration and Internal Labor Flows in the United States. " Economic Geography 68, no. 3 (July 1992): 234-248.

Washington, Booker T. "The Atlanta Exposition Address." Up from Slavery as reprinted in Three Negro Classics. New York: Avon Books, 1965, 145-157. 